\title{
Justiça \& Cidadania: Aportações de Direito \& Arte
}

Justice \& Citizenship: Contributions from Law $\&$ the Arts

\section{PAULO FERREIRA DA CUNHA'}

GALILEU - REVISTA DE DIREITO E ECONOMIA - e-ISSN 2184-1845

Volume XIX $\cdot 1^{\text {st }}$ July Julho $-31^{\text {TH }}$ December Dezembro $2018 \cdot$ pp. 28-48

DOI: https://doi.org/10.26619/2184-1845.XIX.2.1

Submitted on October $25^{\text {th }}, 2018$. Accepted on November $11^{\text {th }}, 2018$

Submetido em 25 de Outubro, 2018. Aceite a 11 de Novembro, 2018

RESUMO O presente artigo visa uma perspetiva epistemo-metodológica pós-disciplinar, na senda dos estudos da macrofilosofia de Gonçal Mayos, procurando colocar em diálogo Direito e Pintura.

O seu objeto é captar por diversos ângulos aspetos salientes do diálogo entre Justiça (e Direito) e cidadania, num tempo de crise para ambos. Recua às questões da ordem social natural ou construída para desaguar nas grandes interrogações políticas da contemporaneidade.

Palavras-chave Justiça, Cidadania, Arte e Direito, Arte.

ABSTRACT The present article aims at a post-disciplinary epistemological-methodological perspective, in the path of studies of the macrophilosophy of Gonçal Mayos, seeking to put into dialogue Law and painting.

Its purpose is to capture from various angles aspects of the dialogue between Justice (and Law) and citizenship, in a time of crisis for both. It goes back to the questions of the natural or constructed social order to pour into the great political questions of contemporary times. KeYworDS Justice, Citizenship, Art and Law, Art. 


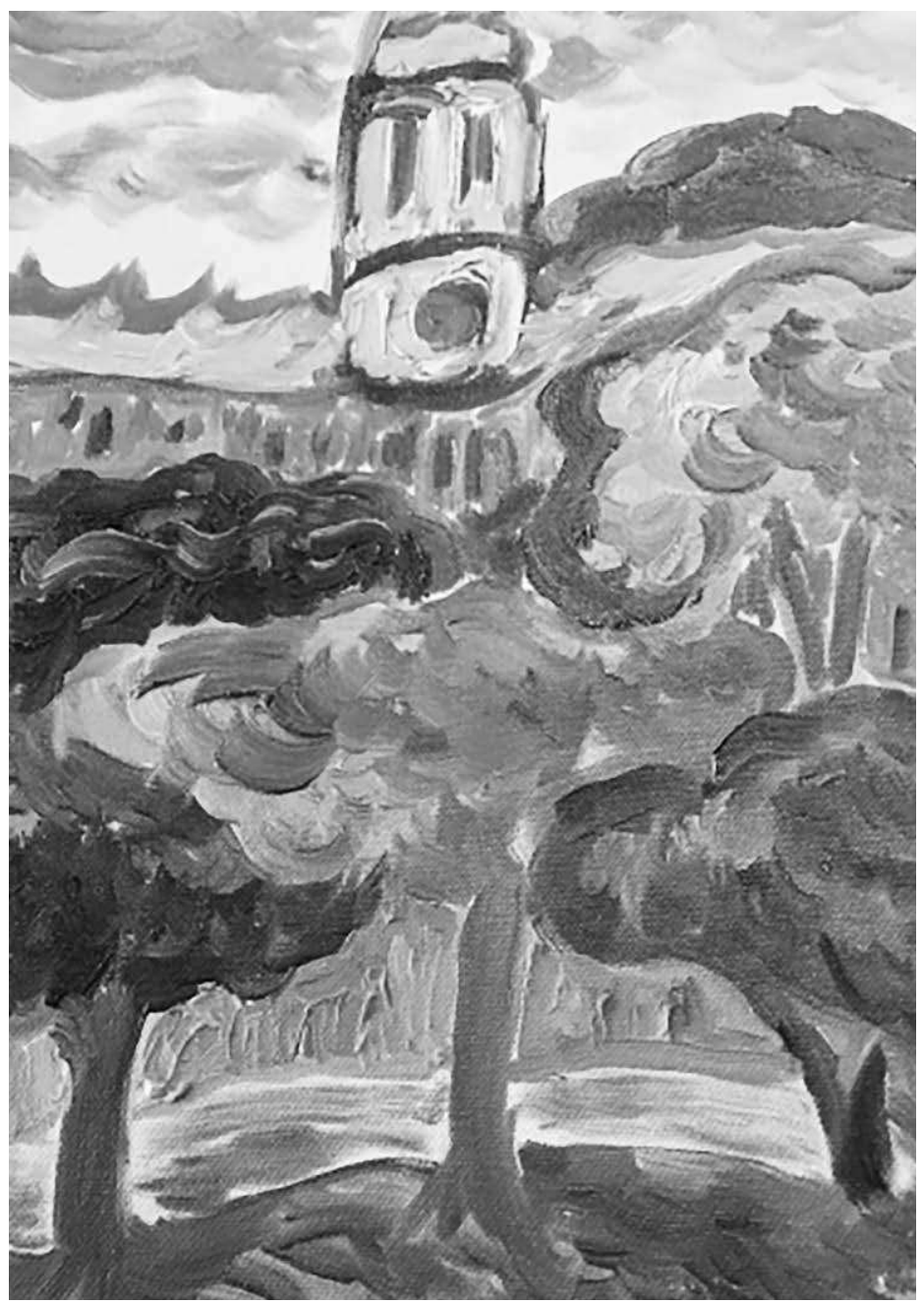

("A Torre e o Rio" - óleo sobre tela, Porto, abril de 2018).

\section{Nomos / Taxis. Ordem Natural e Ordem Artificial}

Antes de se falar do Direito, e muito antes de se falar da Cidadania, tem de se procurar entender o que é (o que será ou possa ser: porque nestas matérias há muito de insondável) a (ou uma eventual) ordem das coisas, seja ela natural ou social. O Direito e a Cidadania desenham-se sobre uma tela de ordem, ou de desordem? Deveria ser sempre de ordem, evidentemente. E essa ordem implica ainda a dimensão humana da mesma: a questão da 
natureza ou condição humana ${ }^{2}$. Ordem de coisas, ordem de pessoas - natureza das coisas, natureza humana...

Os antigos burgos, medievais ou anteriores, como a cidade do Porto, em que nasci (e que a imagem vagamente lembra, em composição livre) eram entidades naturais, que cresciam como a vegetação, com uma dinâmica orgânica. E daí a tortuosidade das suas vias, ao contrário do traçado racional de cidades mais tardias, movidas pelo utopismo planificador: que também tem a sua sedução, mas é algo de bem diverso. Mas a Cidade (as cidades em geral) é hoje, com as organizações urbanísticas, um exemplo de táxis, não de nomos.

Esta dicotomia essencial e paradigmaticamente útil foi recordada nomeadamente em Direito, Legislação e Liberdade, por Hayek ${ }^{3}$. Mas não cremos que tenha um cunho ideológico muito significativo.

Cremos assim que a distinção nomos / táxis é perfeitamente assimilável por qualquer tipo de pensamento (nele integrável), pelo menos se não for excessivamente englobador, unicitário, totalitário. Não é que ela prove que o natural é o capitalismo anárquico e o artificial o que o não seja (mesmo um discreto e capitalismo regulado de economia social de mercado num Estado suavemente, timidamente, social). Uma coisa são normas naturais. No limite, as agraphoi nomoi ${ }^{4}$ invocadas por Antígona contra Creonte no conhecido mito de Édipo, admiravelmente posto em cena na peça Oidipus Tyranos, ou Oedipus rex, na sua versão latinizada, por Sófocles (que desenvolve o tema, nos seus vários aspetos, antecedentes e desenvolvimentos, nas diferentes peças do Ciclo Tebano5).

Trata-se nesse caso de leis não escritas, superiores às escritas, às postas voluntariamente pelas sociedades ou pelos seus governantes (como era o caso de um decreto de Creonte punindo um morto com o não sepultamento: embora a questão seja mais complicada, como explicou um Stamatios Tzitzis ${ }^{6}$ ). Pode remeter-se, assim, para o Direito Natural ou, pelo menos, para a lei natural. São Tomás de Aquino, numa dificilmente superável classificação da normatividade, na Suma Teológica7, explica os vários tipos de leis e Direito. Assim, o Direito Natural é Direito, é juridicidade, mas a lei natural é aquela que está inscrita no

2 Cf. o nosso livro O Ponto de Arquimedes. Natureza Humana, Direito Natural, Direitos Humanos, Coimbra, Almedina, 2001.

3 HAYEK, F. A. - Droit, législation et liberté. I - Règles et ordre, trad. fr.. Paris : PUF, 1973.

4 BARROS, Gilda Naécia Maciel de - Agraphoi Nomoi. São Paulo: "Notandum", vol. 3, ed. online: http://www.hottopos. com/notand3/agrafoi.htm. Ultimamente consultado em 29 de agosto de 2018.

5 Tragiques Grecs. Eschyle / Sophocle. Paris: Gallimard, 1967.

6 TZITZIS, Stamatios - Introduction à la philosophie du droit. Paris: Vuibert, 2011. Idem - La Formation du droit en Grèce, in Instituições de Direito, org. nossa, vol. I, Coimbra : Almedina, 1998, p. 191 ss..; Idem - La Philosophie Pénale. Paris: P.U.F., 1996, trad. port., notas e comentários de Mário Ferreira Monte. Filosofia Penal. Porto: Legis, 1999.

7 Uma edição que usamos normalmente é a Summa Theologiae, trad. fr., Somme Théologique. Paris: Cerf, 1984-86, 4 vols.. Mas há muitas mais... 
coração dos homens, ou seja, é afinal uma forma de consciência moral - isso já o tinha visto São Paulo, e mais tarde será glosado por outros, como o próprio Jean-Jacques Rousseau.

Assim, nomos pode ligar-se aos aspetos naturais da moralidade e da juridicidade (sabe-se que antes do corte epistémico romano, estavam ligadas, aliás, com a política, a religião, etc., no que se convencionou por chamar "primeira" função "política" dos indo-europeus). Nomos não é a cidade: é a vegetação e é o rio. A natureza neste estado é que corresponde à ordem natural. Claro que, como acabamos de ver, também há coisas humanas submetidas ao Nomos. Mas afora alegorias de Antígona e outros heróis da Justiça, são difíceis de representar.

A torre da cidade (e é uma torre civil, não um campanário) é que simboliza a táxis, ordem artificial, voluntária, querida. Não nascem torres nas planuras, não crescem palácios nas florestas. Têm de ser construídos. Assim como as leis humanas, leis positivas, necessitam de legisladores.

A integração harmónica entre natureza e cultura é sempre o grande segredo: da cidade de betão ou de pedra com o que nela há de verde e água e pedra não trabalhada, terra, etc. Assim, do que se trata em Direito é que o Direito da cidade, o correspondente aos palácios e às torres, esteja em harmonia com o Direito Natural. O qual não é direito ambiental ou da natureza física, mas da natureza moral, de que a física pode eventualmente ser uma metáfora. Por vezes, até, uma metáfora ao contrário: Porque o Direito Natural é o contrário de uma natureza desregrada e sem ordem, a chamada "lei da selva".

Mas insistamos na metáfora positiva: rio e vegetação, naturais, enquadram e na verdade até se sobrepõem à torre e ao esboço de palácio. É o natural que deve determinar o positivo. É o Nomos que tem de comandar a táxis. E que o capitalismo é táxis é curioso que foi tese do bom selvagem de Rousseau, e da Origem da Família, da Propriedade e do Estado, de Engels, baseado em Lewis $\mathrm{H}$. Morgan e nas notas à margem que Marx escreveu no seu Ancient Society ${ }^{8}$. Hoje, como aflorámos já, há outros autores em cena, e a polémica continua. Porém note-se: táxis ou nomos, as coisas valem pelo que são. Em princípio, tem-se nomos por bom sistematicamente. Menos a dita "lei da selva". A é evidente que o Direito positivo é uma forma de táxis que deve basear-se no nomos.

8 ROUSSEAU, Jean-Jacques - Oeuvres Complètes. Paris: Seuil, 1971, 3 vols.. Muito especialmente o Contrato Social e o Discurso sobre a origem e os fundamentos da desigualdade entre os homens. trad. port., Porto: Athena, 1964. ENGELS, Friedrich - A Origem da Família, da Propriedade Privada e do Estado. n/ ed. trad. port. de H. Chaves. Lisboa: Presença, s.d.. MORGAN, Lewis H. - Ancient Society, or researches in the lines of Human Progress from Savagery through Barbarism to Civilization. Londres: Mac Millan, 1877. V. ainda, v.g., ALVES, João Lopes - Rousseau, Hegel e Marx. Percursos da Razão Política. Lisboa: Livros Horizonte, 1983. 
Por tudo, é melhor manter a questão do Direito Natural fora da physis física não culturalizada, e colocá-lo ao nível pelo menos de alguma Razão9. Foi o grande projeto iluminista do séc. XVIII, um Direito Natural racional. Mesmo analisando alguns passos de Tomás de Aquino não podemos deixar de entrever nele muito de Razão, de racionalidade...

Não olvidemos também que, acima da torre, estão nuvens. Digamos que, na perspetiva tomista, elas poderiam simbolizar a lei divina. Mas só olha para cima quem quer... Não é necessária essa dimensão para que possa haver ao menos alguma Justiça na terra, como sublinharia, talvez pela primeira vez, Hugo Grotius, um dos fundadores do Direito Internacional Público, como se sabe.

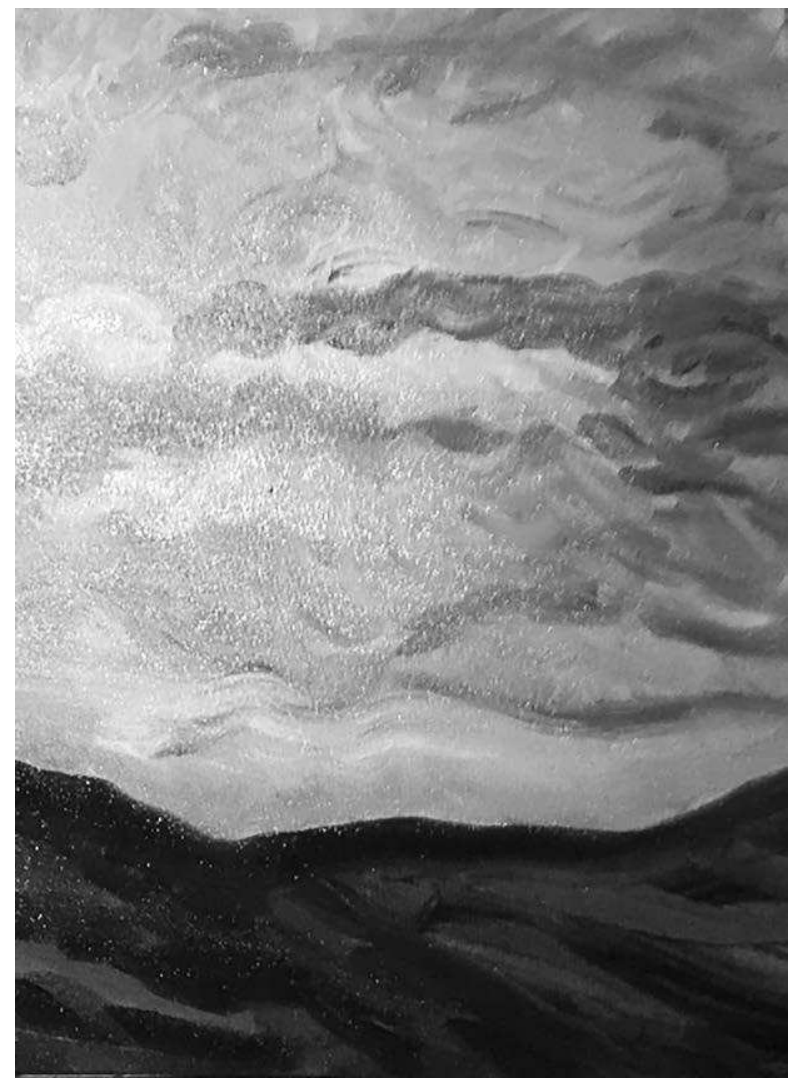

("Anunciação" - óleo sobre tela, Porto, abril de 2018). 


\section{Direito, Sentidos, Mentalidades, Ética}

Janelas da Alma são os olhos. Na verdade, são-no todos os sentidos. O Direito tem uma ligação curiosa, interessante, significativa com os sentidos, como desenvolvemos no nosso livro Le Droit et les sens ${ }^{10}$.

Não parece que o Direito, que precisa de ser prudente (veja-se, desde logo, a expressão Juris-prudência, que tanto significa as decisões dos juízes como a totalidade da scientia iuridica), e portanto tem absoluta necessidade de conhecer todos os dados dos problemas que lhe é dado resolver, como "medicina da cultura", "tradutor universal", grande mediador, possa dar-se ao luxo de desprezar nenhuma fonte de conhecimento sensível. Precisa, evidentemente, de utilizar todos os sentidos. Assim, mesmo o olhar, que já foi considerado fonte de possível queda de favoritismo, mesmo o olhar, insistimos, deve ser utilizado.

Não nos iludamos com o que nos tem sido dito, há uns tantos séculos: Uma Justiça cega não pode julgar bem. Não é eliminando a tentação ou os fatores de risco que se supera o problema. Pelo contrário: o Direito deve bem ver o rico e o pobre, o feio e o bonito, tudo o que seja fator de sedução ou de repulsa, e mesmo assim vendo deve ser imparcial. Porque o problema não está na janela, no olhar, mas na cabeça e no coração do julgador. E o julgador, como o Rei Salomão (que via bem os pleiteadores, e quase o vemos a tocar-lhes), deve ter, antes de mais, "um coração inteligente", que é também conceito retomado por Alain Finkielkraut, no seu livro homónimo"

Hoje em dia fala-se muito, como discurso legitimador (entre nós desde João Baptista Machado) ou psitacista, de "janelas de oportunidade" como sinónimo quase de "crise é oportunidade" e outras manifestações da síndrome do limão doce. Evidentemente, estes discursos legitimadores, embalos da consciência crítica, têm sempre algo de verdade - como bem observou o poeta popular António Aleixo: "p'ra mentira ser mentira / e atingir profundidade / tem de trazer à mistura / qualquer coisa de verdade". Mas é dessas janelas que curamos. Também houve janelas de que se lançaram idosos despejados de suas casas durante a crise em Espanha - segundo foi noticiado...

As janelas de que falamos aqui são outras ainda, embora deva ficar o registo de todas. As janelas são as janelas do próprio ser, da própria circunstância (no singular, como em Ortega y Gassett, claro: não com o plural do barbarismo superficial de quem não o leu), são o necessário alargar de horizontes.

E é esse o nosso desejo doutrinal, o de abrir janelas para que possa haver renovação de ar, e mudança de vistas. Janelas para outras paisagens, para outros mundos. 
Os anquilosados e os lunáticos vivem universos paralelos. Eles são por vezes confluentes ou involuntariamente cúmplices - como no rendimento universal garantido, que para os mais quiméricos bem intencionados seria uma cornucópia de abundância para todos (novo "país de cocanha"), talvez por uma suposta redistribuição do grande bolo da acumulação da riqueza, mas para outros, mais céticos, é apenas uma forma sinuosa de se acabar a prazo com a segurança social nas suas mais variadas formas: pois se toda a gente já tem esse rendimento, nada mais de facilidades advindas do Estado. E é óbvio que tal rendimento, em concreto, porque muito baixo (veja-se o salário mínimo português... e é remuneração de trabalho!) não chega. Bom negócio, pois, creem os segundos, para os que são jurados inimigos do Estado social. Para não falar já do desincentivo ao trabalho e na criação de uma mole de (semi)pobres subsidiodependentes, potencialmente uma bomba social como clientelas de demagogia de quem lhes prometa aumento de subsídio (ou, surpreendentemente, o contrário! A massa amorfa reage a tudo e ao seu contrário em situação de populismo narcotizante). E aponte estes ou aqueles bodes expiatórios como culpados pelos males de todos...

De qualquer maneira, aguardam-se mais argumentos de parte a parte... Seja como for, é um exemplo de confluência entre uma cultura anti-trabalho, certamente laxista, e uma cultura meramente economicista, que conta que sempre alguns trabalharão, sendo melhor esvaziar o Estado (ou colocá-lo restritamente ao serviço dos grandes) através de um pretenso igualitarismo muito por baixo... No meio de ambas as perspetivas, certamente há moderados com boas intenções... Nomeadamente se fizeram as contas e chegaram à conclusão de que se pode dar uma espécie de abono de família vitalício. Em que medida seria compatível com o Estado social e o incentivo ao trabalho? Teria o lado negativo da criação de ociosos? É um caso difícil para provar, mas certamente um desafio...

Enfim: uns vivem no passado, no porão, ou na masmorra do castelo interior (que não é obviamente em nada semelhante ao de Santa Teresa de Ávila ${ }^{12}$ ), outros num universo puramente mental, precisamente fechado à realidade. As pessoas meio sonâmbulas entreabrem de tempos a tempos as janelas da sua morada, mas timidamente, só para arejar, numas anuais limpezas na primavera...

Ora a ideia é deixar as janelas abertas. Dormir mesmo de janelas abertas sem medo dos ladrões de sonhos e de bens... Abrir as janelas para abrir as mentalidades.

O sociólogo Gaston Bouthoul estudou bem a categoria sócio-cultural "mentalidades", caracterizadora das sociedades, mas também dos estratos e grupos sociais mais particula- 
res, dentro de civilizações e culturas. E começa o seu livro já clássico Les mentalités ${ }^{13}$ precisamente sublinhando como as diferentes mentalidades, desde a Antiguidade, geram antagonismos de hostilidade profundíssimos entre tribos vizinhas que tudo teriam, além disso, para até nem sequer se singularizarem demasiado.

Também hoje as mentalidades e as cada vez maiores divisões de "tribos", mesmo tribos urbanas, enfunadas além do mais pela moda e o consumismo (de vários tipos) contribuem muito para desunir as pessoas, e para as individualizar... Ora sem prejuízo de não se desejar um mundo cosmopolita no mau sentido, sem desinências, sem especificidades, sem localismos, e desde logo sem Línguas específicas e costumes próprios (e Leis que espelhem essas diferenças), é preciso dialogar, é preciso entender os outros. O princípio republicano implica uma universalidade de soluções, e não a eterna desculpa, a eterna exceção, em que, por exemplo em nome de tradições locais ou de grupo, se contrariam leis gerais - atentando contra direitos de mulheres e menores, contra os deveres das pessoas para com os animais, contra interdições de consumo de certas substâncias (quando tal seja justificável), e muitos outros casos. Pascal é sempre citado quanto à diferença que faz, nos conceitos e preconceitos, nos costumes e mesmo nas leis uma mudança de latitude, ou o atravessar um riacho, ou, mais ainda decerto, os Pirenéus ${ }^{14}$. Mas isso implica mudanças de país para país, não dentro de uma mesma ordem jurídica.

A perspetiva de Pascal dá que pensar. Há coisas que tanto o são na Grécia como na Pérsia, como o fogo arder (lembremos agora Aristóteles). Mas há outras coisas que são diferentes na Grécia e noutros lugares. O mesmo Bouthol lembra, com acerto, que o Estagirita não recolheu (aparentemente) as Constituições de muitos países fora da Hélade. Fê-lo para Cartago, e pouco mais, se o fez (como se sabe, perderam-se muitas das Constituições que sociologicamente recolheu com os seus discípulos)... Porque certamente a forma constitucional no sentido mais elevado da Pólis grega era desconhecida daqueles a quem os gregos consideravam barbaroi.

Mas hoje o conceito de bárbaro tem toda uma outra dimensão. O bárbaro é o novo-rico ou o Lumpen no interior das nossas sociedades, não o refugiado, quantas vezes mais culto e letrado que os seus patrões novos-ricos, quando consegue arranjar emprego na Europa. O bárbaro é o estudante que ostenta essa qualidade (de estudante) só para ter descontos em maus espetáculos e coisas afins e não aproveita a enorme oportunidade que a sociedade e o Estado lhe dão. Que se crê intimamente (e por vezes até o exterioriza) com direito a diploma pela simples matrícula. O bárbaro é o possidente que se sente com direito a explorar sem 
dó todos os que lhe venham a cair nas mãos (que acha que, no fundo, o bom seria ter escravos: e alguns quase já o admitem abertamente). O bárbaro é o que procura viver à custa de subsídios, mordomias, esquemas, que recebe roupa limpa de entidades caritativas e não se dá ao trabalho de a lavar: deita-a fora e vai buscar mais roupa, como mais comida, tudo... $\mathrm{E}$ muitos mais.

O problema é, assim, a abertura de mentalidades (a par do discernimento ético e da prática ética). O que tem que ser uma enorme revolução mais que cultural anímica, multidimensional. Enquanto o explorador viver subjugado pela sua ganância, o subsidiodependente e o cábula pela sua preguiça, o laxista pelo seu spleen e amorfismo moral, caminharemos apenas com as pernas e a cabeça de uns tantos, e transportaremos às costas o peso morto de muitos, por estas e aquelas razões. E seremos, continuaremos a ser, sociedades de infelicidade.

Enquanto isso, resistindo, há algumas tábuas de salvação: uma delas é a Ética Republicana, de que falamos bastante no nosso livro Para uma Ética Republicana $a^{15}$. A sensação de, contra ventos e marés, cumprir o seu dever, é um bálsamo contra o desconcerto do mundo. Por vezes não há mais nada a fazer do que ficar no único lugar em que não há cedência a terrível corrupção, em que se não violenta a consciência. Sempre vem à lembrança, nestes casos, a ideia de que por vezes nem sequer se trata de heroicidade dos que são inflexíveis numa posição de coerência: por vezes é apenas impossibilidade intrínseca, estrutural, incapacidade de agir de outra forma, por graves que sejam as consequências. Talvez fosse isso que Martinho Lutero queria dizer quando, na dieta de Worms, declarou: "Hier stehe ich. Ich kann nicht anders".

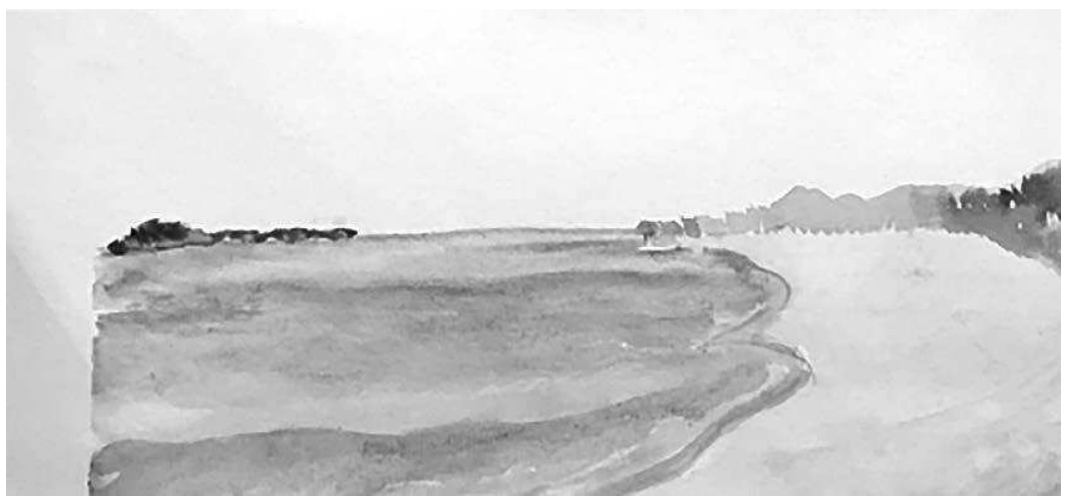

(“Oásis marítimo" - aguarela sobre papel, São Paulo, maio de 2018.)

15 V. o nosso livro Para uma Ética Republicana. Lisboa: Coisas de Ler, 2010. 


\section{Modalidades da Justiça}

Há uma estória popular de um "Frei João sem Cuidados" a quem um rei invejoso (porque cheio de canseiras e preocupações: governar em geral dá trabalho, seja o que for...) um dia tentou encostar à parede com três adivinhas capciosas, mas, graças ao auxílio de um homem livre, um moleiro (os moleiros eram pessoas livres - veja-se o livro de Carlo Ginzburg, O Queijo e os vermes), acabou por confundir o monarca e ver-se livre de apuros.

O cidadão sem cuidados talvez necessite, por vezes, da ajuda de um defensor, de um representante, no fundo, de um advogado, para conseguir livrar-se dos ataques dos poderosos, que não precisam de ser reis para colocarem um bom paisano (ou citadino...) em apuros. Podem ser até marginais com qualquer acesso aos mecanismos da justiça, que conseguem por vezes acionar contra cidadãos de bem - que perdem o seu descuido, de tão estupefactos e confusos que ficam, porque acreditavam que pessoas que cumprem o seu dever não seriam nunca incomodadas com suspeitas e mais ainda que isso... A situação de vulnerabilidade dos cidadãos sem cuidados é digna de especial proteção, porque eles, ao contrário dos infratores profissionais, dos manobristas, dos "videirinhos", e todo um sem-número de categorias de sabidos e desonestos, caem das nuvens da sua ingenuidade e não se sabem defender. O que pode ser dramático.

O cidadão sem cuidados, em situação normal, ao mesmo tempo dorme bem à noite porque tem a consciência tranquila (isso depende sobretudo de si mesmo), e ainda está em paz com o mundo, porque o mundo lhe não cobra demasiado.

A alma só pode ser recuperada sem o frenesim quotidiano, seja ele laboral(ista), espremendo a força de trabalho até ao tutano, seja o palácio da loucura das burocracias, que tornam a vida do cidadão um instrumental cirandar para nada... para apenas alimentar a máquina da burocracia. E assim fica a pessoa (o cidadão é antes de mais uma pessoa) esgotada, sem propósito, sem vida, sem alma.

As nossas sociedades não são muito propensas à existência de cidadãos sem cuidados. Pelo contrário. Parece que tudo, das complicações laborais às que vivemos por empatia através da comunicação social, passando pelas vidas pessoais cada vez mais vazias, solitárias e conflituosas, tudo contribui para o stress. A Doutrina do choque, de Naomi Klein, é muito eloquente ${ }^{16}$. Parece, na verdade, que vivemos um "capitalismo de desastre", e somos tratados como cobaias com choques elétricos. Somos ensinados a viver crises, cataclismos, débacles... Isso nos mantém docilizados... 
Fala-se agora em vacina contra o stress, o que é um passo mais no caminho do Brave new world: passando os cidadãos ainda mais à condição de drogados, para poderem ir suportando os fardos.

No oásis marítimo aqui retratado o tempo é nosso. E temos todo o tempo que a vida nos permitir.

Pepe Mujica avisa que ao consumirmos coisas nesta nossa sociedade baseada nesse mesmo consumismo estamos a pagar com tempo de vida: e há um filme notável, O Preço do Amanhã, em que tal troca é desenvolvida e levada aos limites: tudo se paga em tempo de vida).

Evidentemente que a fruição pura à beira mar, olhando o céu e o mar em harmonia, não pode ser para todos, dado que Adão foi condenado ao trabalho. Mas pode haver trabalho compatível com fruição. O problema é o da Justiça na sociedade. Que já era o primeiro problema de Platão, e de onde brota a República, ou Politeia. Vários autores, depois dele, considerarão, com efeito, que a resposta à pergunta sobre a Justiça reside em encontrar o homem justo (será o caso de Santo Agostinho, por exemplo). Mas, sem prejuízo de ser uma verdade (a qual tem evidente atualidade) que não há cidade justa sem homens justos (e daí, num plano religioso - e metaforicamente, decerto, também num plano moral -, que Sodoma e Gomorra pudessem ter sido salvas se nelas houvesse apenas dez justos ${ }^{17}$ ), temos também que dar razão a Platão, ao pensar que o contexto social de Justiça é essencial para que haja pessoas justas. Donde a indagação sobre a Justiça, em Platão, passar a ser, na República, a demanda da sociedade justa. Sabe-se bem que, no confronto entre o ideal e o real, o filósofo da Academia foi descendo a fasquia em subsequentes obras e que a utopia (é, na verdade, uma verdadeira utopia) Politeia, como aliás ocorre mesmo com muitas eutopias (boas utopias, utopias pensadas para serem benéficas), pelo menos aos nossos olhos modernos e liberal-democráticos de hoje não seria uma sociedade tão excelente para se viver. O mesmo se diga, aliás, desde logo, da Utopia de Tomás Moro.

Nunca resolveremos as angústias existenciais profundas de alguns, nunca daremos tudo aos ávidos de universos, nunca estará contente o intrinsecamente mal disposto, é realmente insaciável a sede e fome de poder, de prazer, de riqueza de alguns. A esses uma sociedade justa, harmónica, bem organizada não convém de forma alguma. Mas à esmagadora maioria das pessoas, se bem educadas (não formatadas, não manipuladas, mas mostrando-se-lhes os seus interesses coletivos e individuais bem entendidos), pode satisfatoriamente dar-se cumprimento às suas necessidades fundamentais, estando obviamente nas mãos de cada um ir mais além e ir pelo seu próprio caminho. Mas é possível (e há casos pontuais 
de planos bem sucedidos de justiça social - na saúde, por exemplo, Portugal até está bem cotado, apesar de todos os problemas que o Serviço Nacional de Saúde sofreu) a justiça social.

E num contexto de justiça social também é possível um trabalho com rosto humano, em que o trabalhador seja protagonista, criador, e não escravo, quaisquer que sejam os eufemismos (ou não) com que pintem a sua nova condição. Aliás agravada pelos meios de permanente controlo e contacto por via das novas tecnologias.

Poder-se-á trabalhar e viver descansado, sem incompatibilidade. O oásis não é uma miragem. Parece, claro, quando há quem advogue que um trabalhador não precisa de mais de 15 minutos para almoçar, e que deve comer uma sandes com uma mão e trabalhar com a outra... Quando até uma horita de intervalo de almoço é regateada a quem trabalha compreende-se o clima de escravatura e de verdadeira exploração para que se caminha, e em que, em grande medida, já se está. Nunca pensamos que estas coisas fossem possíveis no século XX, que fará no XXI. Mas estão a ser. E enquanto isso militantes aguerridos não parecem muito comovidos com estas situações, lateralizando as reivindicações, apontando para o lado... Procurando, em vez de mais igualdade de todos, para todos, e mais fraternidade entre todos, e mais liberdade para todos, abrir feridas, criar novas, barricar grupos, incitar corporativismos, alimentar mal-entendidos e soprar no fole dos conflitos.

Só pode haver direito ao livre desenvolvimento da personalidade com um equilíbrio entre o ser social e o ser pessoal, individual, com uma harmonia entre trabalho e lazer. E as coisas belas, designadamente da natureza, são uma grande ajuda, em todo o caso. São, hoje, em boa medida, um refúgio para quem pode. Mas poderão ser amanhã um bem de fruição geral, livre, para todos... A natureza e a beleza podem ser quase inesgotáveis. Assim as saibamos preservar a uma e cultivar a outra.

Importará finalmente deixar esclarecido que há uma certa higiene mental positiva, salutar, em regressar a Aristóteles (e São Tomás de Aquino, que o retomou) e dividir a justiça em duas (nesta sede, porque há muitas divisões possíveis).

De um lado, está aquela a que chamaríamos “justiça particular, ou jurídica”, e que tem como objeto o Direito, que para ela caminha (ou de quem ela é mãe, como diz uma glosa medieval). Essa é a "constante e perpétua vontade de atribuir a cada um o que é seu". O seu (suum) de cada um é que, nela, é o direito, o seu direito de cada qual (suum cuique). Mas evidentemente que os Romanos, que criaram esta descrição lapidar, sabiam bem que, embora tenha de ser uma procura e uma atribuição quotidiana, implica também constante e perpétua vontade: ou seja, nunca se consegue alcançar na plenitude. Tinham, pois, os práticos Romanos a noção da falibilidade e incompletude da Justiça em cada tempo e lugar. A busca do 
suum obriga a indagações técnicas complexas, por vezes, procurando-se o título jurídico que funda o direito (ou a pretensão).

Mas chega-se a breve trecho, se se tiver alguma consciência de Justiça, à conclusão que, se apenas se atribuir a cada um o que lhe venha por título jurídico simples, positivista, o pobre fica pobre e o rico fica rico, e por vezes o pobre cada vez mais pobre e o rico cada vez mais rico. Ou seja, como na sua reflexão sobre a Justiça, no Diário de Alcestes, referiu o filósofo luso-brasileiro Agostinho da Silva, o Direito acabará por ser uma sebe (ou um muro) que dividirá segura (e injustamente) os choros dos risos...

Esta secura positivista do titularismo (mesmo do jusnaturalista) levou a que se incluíssem nos títulos jurídicos a natureza ou condição humana. Evidentemente, é complicado afirmar a existência ontológica da primeira, hoje em dia, depois da antropologia e do existencialismo, segundo alguns, mas é fácil ver que existe uma segunda - veja-se o trabalho de fotografia de Sebastião Salgado. Fiquemos, então, com a simples condição humana, embora suspeitemos que não seja apenas "condição"... Mas não polemizemos agora.

Esta inclusão da condição humana entre os títulos que contribuem para dar alguma coisa a alguém obriga a considerar a dignidade da Pessoa em termos práticos, e e fundamenta rendimentos mínimos garantidos, rendimentos sociais de inserção, enfim, a prestação social pelo Estado de um mínimo de subsistência, assim como serviços públicos mínimos - desde logo de saúde e educação.

A partir desta inclusão (e já pelos exemplos dados de sua concretização, e muitos mais haveria, pelo mundo fora) fica muito fácil compreender que a Justiça Social, que para alguns, mais rigoristas e titularistas (ou simplesmente positivistas legalistas) era uma quimera mais ou menos revolucionária e subversiva, pelo contrário se integra nas dimensões normais da juridicidade. Não se trata de uma perversa ideologização de um Direito pretensamente puro. Trata-se de não tornar o Direito um simples jogo abstrato alheio à Justiça concreta, material, real.

É assim possível e necessário considerar, no Direito, um elemento de Justiça Social, sem prejuízo de ela dever ser também perseguida pelos que, na política, de formas muito diversificadas a procuram. Hoje em dia quase todos, de quase todos os quadrantes ideológicos (menos os fervorosos ditos neoliberais) são a favor de uma qualquer fórmula (há várias, e até politicamente adversas e contraditórias, como explicou na sua admirável tese, Do Estado Liberal ao Estado Social, Paulo Bonavides ${ }^{18}$ ) de Estado social que é a institucionalização de alguma versão de Justiça Social. 
Não deixemos contudo de ver alguma distinção: uma coisa é a dimensão mínima de justiça social implícita na defesa da dignidade da Pessoa humana - e que remete para o título jurídico condição humana - e outra coisa é o anelo, ideologicamente tratável (e aqui ideológico nada tem de pejorativo), em várias perspetivas conforme os credos políticos, de implantação de uma sociedade justa, uma utopia (também no sentido rigoroso e não de quimera ou impossivel), ou de aperfeiçoamento da sociedade existente (utopismo ou princípio esperança, de que falava Ernst Bloch, através de várias formas de "reformismo"). Vemos até, felizmente, precedente constitucional de consideração do mínimo de subsistência ou existencial (pouco importa o nome) não, como alguns esperariam, sequer como decorrente de direitos sociais, mas corolário da dignidade da pessoa humana. O que lhe dá, no contexto argumentativo atual, muito maior força.

$\mathrm{Na}$ Arte, o titularismo estrito corresponde ao academismo. E reivindicações utópicas desabridas podem ser, em Arte, vanguardismos sem substrato. Contudo, as consequências destes parecem ser mais inócuas que as dos seus homólogos políticos e jurídicos. E estamos em crer que até um excesso vanguardista em Direito poderá ser mais grave, porque primeiro se fazem as revoluções e depois se passam a limpo, juridicamente... Fazer o contrário é perigoso.

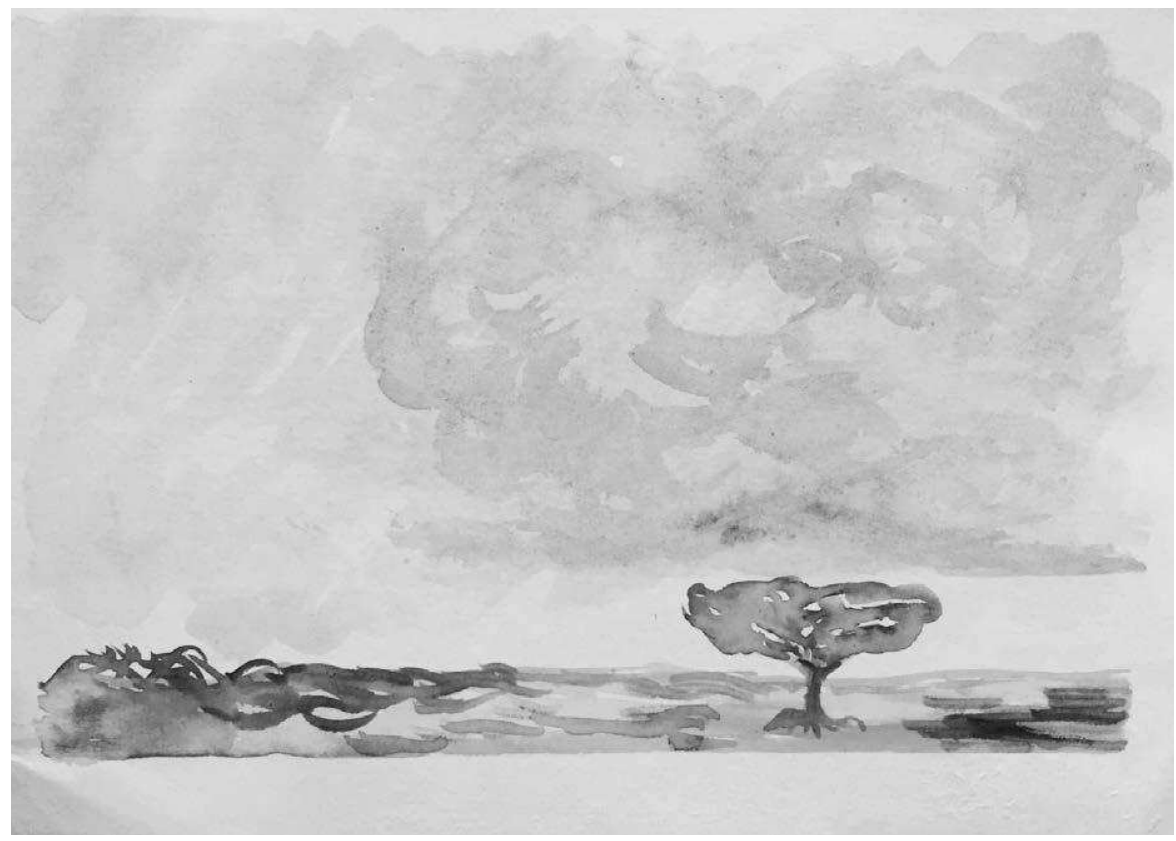




\section{Cidadanias}

É muito corrente hoje, em redes sociais, glosar-se Platão, com mais ou menos rigor, na República, para se dizer, afinal, que o preço de alguém se alhear da coisa pública, e especificamente da política, seria ser-se governado, e comandado mesmo, por pessoas de nível inferior.

Aristóteles, na sua Política, discute a questão sobre qual a opção que seria melhor: vida ativa ou vida contemplativa. E embora se veja, pelas suas palavras, que tem a tentação de se quedar pela calma da contemplativa, uma espécie de imperativo categórico lhe impõe a opção pela vida ativa.

Também é hoje corrente fazer alguma tábua rasa sobre o passado clássico e começar essa discussão por uma sem dúvida excelente e mesmo erudita autora, mas que não inventou o problema, naturalmente: Hannah Arendt ${ }^{19}$. Especialmente remetendo para o seu livro A Condição Humana, e o seu conceito de vita activa, que daria afinal título a um muito interessante filme sobre a autora ${ }^{20}$ :

Outras vozes se poderiam recordar, como é óbvio. O problema afigura-se-nos ter a ver com a fé na capacidade de intervenção no mundo. Não se trata, como para os desportistas ou os ginastas amadores, ou os que querem perder peso ou aumentar endorfinas, de correr por correr, de se agitar ou intervir por intervir - já que sabem que as consequências necessárias da atividade serão para si positivas. A ação, no campo social, político, jurídico, não tem um valor por si (nem de forma alguma garantido), a menos naqueles casos em que é preciso marcar ponto (ou "ditar para a ata") na História para "salvar a alma".

Vale mais uma vida em esfalfar-se permanente sem resultados, ou uma vida bem vivida, com afetos, com qualidade, com confortos, com diálogos, com fruição da natureza e da cultura, e mesmo, para alguns (e deve dizer-se que são hoje cada vez mais, certamente), de comparticipação, cada uma ao seu nível, na cultura e no cuidado com a natureza (que afinal representam uma outra forma de militância e de intervenção: mas mesmo que o sejam de forma leve, souple...)? Posta a questão assim, parece que a primeira se resume a um esgrimir com moinhos de vento, ou com máquinas de guerra tão possantes, ou fortalezas tão inexpugnáveis que a derrota é certa, e daí a imprestabilidade do esforço despendido.

Diríamos então que o grande problema é de vocação. Há um chamamento a ser-se atacante no jogo, ou a preservar-se a retaguarda. A ser-se audacioso como Tomás Moro ou Boécio (embora ambos de uma audácia sempre prudente) ou a ser-se preservador de legados, como Cassiodoro. Quem tem a vontade e a compulsividade da vida ativa, como poderá

19 Sobre a autora, desde logo, por todos, LAFER, Celso - Hannah Arendt. Pensamento, Persuasão e Poder, 2. ${ }^{\text {a }}$ ed., São 
recolher à poltrona e ao cachimbo, fumando congeminações? Quem, pelo contrário, se afoba com as ágoras, se aborrece de morte com as arengas sem propósito de tantos discursos demagógicos, se envenena com o acúmulo de intrigas que há que suportar, deslindar e contra-atacar na política, seja na global e macro-, seja na particular ou micro-, certamente apenas por um imperativo categórico muito categórico e muito imperativo se leva a entrar na atividade cívica mais empenhada.

Claro que a uma pessoa com um perfil mais contemplativo, calma, ponderada, moderada, não repugnará de todo dar o seu avalizado parecer num conselho civilizado, com pares educados, ou algo semelhante. Mas atirar-se para o campo aberto e desprotegido da batalha sem rede, sem garantias, sem escudo até, só no caso de ter tocado a rebate um carrilhão de liberdade ou afim, que obriguem a sua consciência. Mais lhe acaba por convir uma espécie de cidadania passiva, de votante, de (no máximo) subscritor de petições (hoje, aliás, banalizadíssimas), etc..

Acresce ainda que as instituições de uma democracia nem sempre são instituições democráticas. E mesmo, por exemplo, os partidos, os sindicatos, as associações políticas, etc., nem sempre nem em todos os países são modelos de democracia interna. Desde logo, poder-se-á invocar, a este propósito, a chamada lei de bronze das oligarquias, e muito especificamente das oligarquias partidárias, de que foi estudioso pioneiro Robert Michels, já no seu livro sobre os partidos, dos inícios do século $\mathrm{XX}^{21}$.

Isto significa que o bom cidadão entusiasta, que tenha pretensões a ser mais que um colador de cartazes numa instituição de luta pelo poder (e hoje essa tarefa já está terceirizada e sintetizada em apelativos outdoors profissionalmente concebidos e tratados), mesmo com muitos dotes técnicos, empenhamento de fé no credo ideológico respetivo (se o houver) ou fidelidade aos líderes (se existirem com suficiente carisma), com tempo (essencial para investir neste tipo de tarefas) não tem de modo algum garantido que a sua participação seja tida em conta, que o seu contributo seja considerado. Pode, se for simpático e se forem simpáticos consigo, receber sorrisos, palmadas nas costas e um ou outro elogio. Mas a possibilidade de passar a barreira da adesão para a possibilidade de ação e vero protagonismo, mais que explicável por insondáveis teorias da conspiração ou complexos algoritmos das novas ciências, parecem-nos apenas decifráveis pelo mistério profundo da Fortuna, a velha deusa da sorte. Há quem tenha sorte e quem não tenha sorte na política. Assim como no jogo ou nos amores... São sinas. Não depende muito do valor, da inteligência, nem sequer da militância. Esta é uma espécie de bilhete mínimo para a grande tômbola dos "chamados" 
e dos "escolhidos", mas não garante mais que uma vaga possibilidade de participação. E mesmo quem não milite pode, sabe-se lá por que milagre, vir a ser chamado, e normalmente para alto cargo. Talvez nesses casos a visibilidade mediática ou em círculos de poder, fama, negócios, e afins rodas de elites supram, e supram muitas vezes com vantagem, o "dar o litro" dos velhos "coladores de cartazes".

A planura contemplativa da imagem que ilustra este texto remete para um outro mundo, o de uma vida privada, embora ao ar livre (não enclausurada nem ensimesmada). Contudo, ela não está isolada do mundo em geral. Por um lado, o solo em que a árvore se implanta tem seus laivos de revolta, não é total planura. Por outro, o céu apresenta uma certa ameaça de chuva, nos tons violáceos-cendrados que esboça. Entre um solo que pode não ser completamente plácido, e um céu que sugere ameaça, é essa, sempre, a sina da vida contemplativa da árvore altiva, com raízes fundas e copa orgulhosa. Há uma fragilidade na vida privada. Como há um risco na vida pública. Como pode haver frustração na tentativa de participação pública frustrada.

Não há perfeição no Mundo. Não há um caminho apenas, e muito menos uma senda segura.

Não nos esquecemos de não estigmatizar nem o militante puro nem o pacato votante, cidadão "passivo". Ambos podem exercer uma boa cidadania, cada um à sua maneira. E quanto ao dito "passivo", quão salutar e com que positivas influências não será o seu distante e sábio voto, quando vota em consciência e com consciência reta, pelo bem comum?

Entretanto, nos nossos dias há a assinalar também militâncias estranhas, que podem ser alheias às grandes causas sociais de sempre, mas que elegeram apenas nichos do mercado da contestação. Há casos e casos. Alguns de uma bizarria que para alguns será ridícula, outras com pertinência. Não se pode senão analisar caso a caso. Contudo, este tipo de movimentações perturbadoras dos cânones mais tradicionais já têm sido alvo de críticas (embora raramente, cremos que por pressão do politicamente correto, em que se enquadram). As mais interessantes serão aquelas que, como as de alguns comentadores políticos conhecidos, as causas contra corridas de touros ou tabagismo distraem de bandeiras mais urgentes e mais importantes socialmente.

Há ainda medidas claramente discriminatórias de certos grupos ou privilegiadoras de outros, que colocam o debate político e a decisão jurídica e administrativa, por vezes, entre paralelogramos de forças meramente corporativas. Sendo de ter o maior cuidado em discernir quais dessas causas têm relevância social geral, e quais são simplesmente jogos de interesses, camuflados por grandes parangonas e marketing para impressionar a opinião pública e os decisores. 
Não parece, contudo, que a cidadania, quer ativa, quer passiva, se encontrem em boas condições para fazerem hoje um juízo avisado e prudente destes vendavais de novidades reivindicativas (algumas comportando ou trazendo no ventre revoluções inimagináveis ainda), porquanto a formação do sentido crítico necessitaria de uma outra Escola, de uma outra Comunicação social e mesmo de uma Família mais consciente e ativa, todas mais empenhadas nesse fim. Sem tais vetores renovados somos, a maioria de nós, completamente reféns das modas, dos rumores, das manipulações mediáticas.

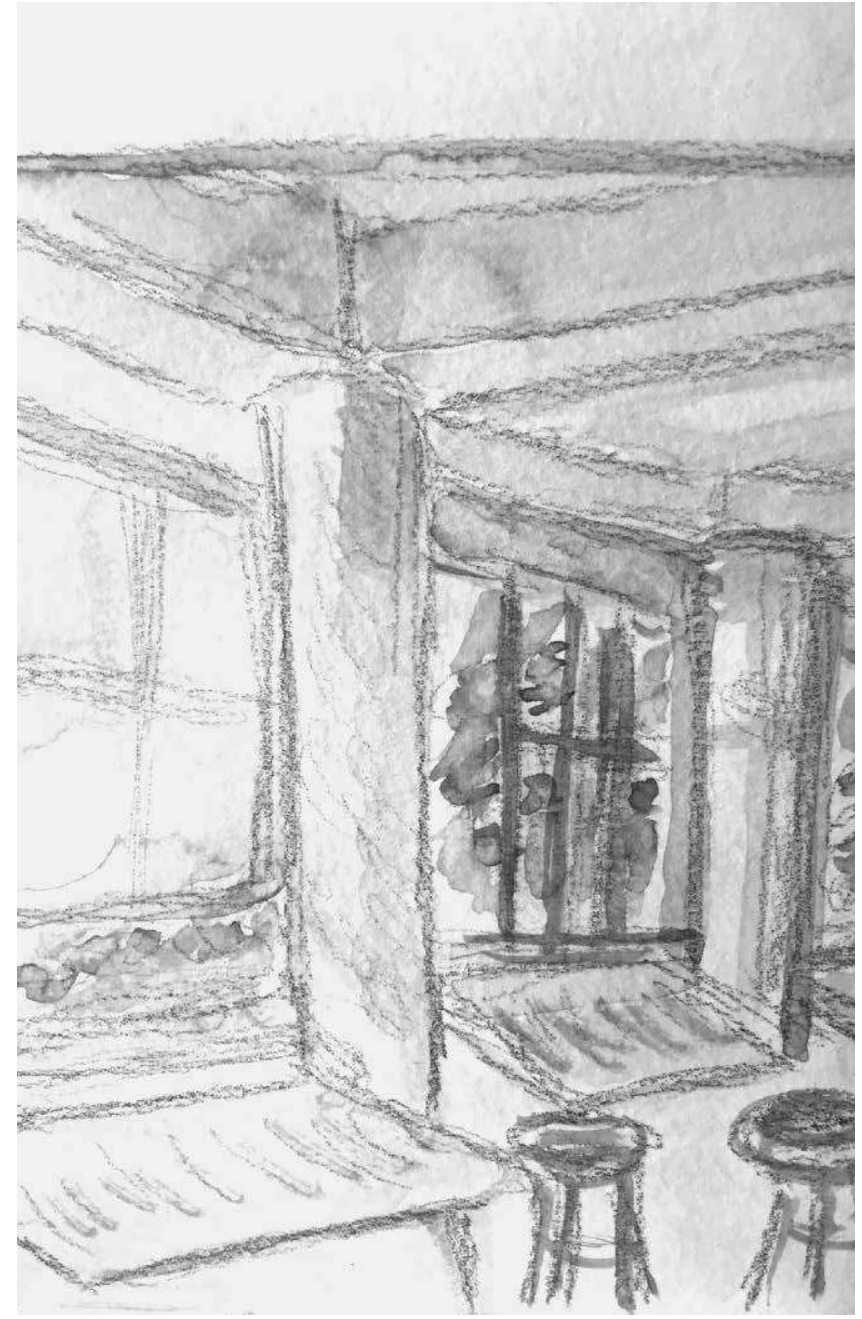

"Sala do Risco" - grafite e aguarela sobre papel - Porto, maio de 2018. 


\section{Riscos, Vitórias, Deontologias}

Casa dos contos, sala do risco, e tantos outros, são nomes mágicos que tinham instituições e lugares antigos, que não vamos aqui desvendar para os não privar do encanto e sabor. Hoje alguns deles foram adaptados a situações e empreendimentos modernos, naturalmente seduzidos pela graça e profundidade das suas metáforas.

O que queremos dizer com o título deste apontamento de uma sala das Belas Artes do Porto, visto à nossa maneira, é a função da sala apenas: riscar. Mas riscar assumindo riscos. Porque criar é isso, sempre. Riscar, pois, no risco. Fazer do risco um risco. Aposta, possibilidade, jogar a cabeça. E jogar a cabeça, arriscar tudo, já nos remete para etimologias gregas de palavras ligadas à governação, ao reinar. O que reina joga a cabeça, põe a cabeça no cepo.

A Arte também tem muitas decisões a tomar, e em cada uma a obra pode perigar. O risco é comum à política e à arte.

O Direito interiorizou muito a ideia de risco (que estava já esparsa em várias temáticas de responsabilidade, crime, etc.) ao ir beber nas perspetivas sociológicas de Ulrich Beck, que chegam a caracterizar a sociedade atual como "sociedade de risco" (Risikogesellschaft) 22 . Podemos dizer que espadas de Dâmocles várias impendem sobre as nossas cabeças, mas a eutopia, a utopia positiva, não deveria ser perdida de vista: uma sociedade não de plácida e aborrecida segurança sem aventura. Mas aventura com muita segurança, apesar de tudo.

O mundo moderno vende pacotes de aventuras, enaltecem-se desportos mais ou menos radicais. Há contudo, para além do lúdico, de perigos que se enfrentam pelo simples propósito de fazer subir a adrenalina ou de ganhar um qualquer fútil troféu, há contudo, realmente, muitas aventuras que valem a pena, que comportam risco, e que, no perigo, garantem a glória verdadeira aos que conseguem vencer (para glosar um dito de Corneille).

Portanto, e seguindo o autor do Cid, para haver glória é preciso que o triunfo tenha conseguido vencer o perigo (A vaincre sans péril on triomphe sans gloire). Mas decerto no tempo dele não seriam tão frequentes as gloríolas fátuas de coisas perigosas sem propósito... Que sabemos nós?

Um outro requisito haverá, assim, a acrescentar, seja como for: a glória só pode advir de um perigo corrido com interesse, com importância, por uma causa nobre, importante, e por um motivo virtuoso. Assim, está completamente certa a canção Victime de ma victoire: "A vaincre sans vertu on triomphe sans gloire"23.

Como essa questão se coloca no Direito! Ganhar uma causa por ínvias vias? Aceitar um caso duvidoso? Aceitar defender um facínora? - questões clássicas para aprendizes de juristas, 
que os grandes autores da deontologia, de Maurice Garçon a Rafael Gómez Perez e em Portugal António Arnaut, por exemplo, facilmente dilucidaram já24.

Há sempre, contudo, um pequeno aguilhão da consciência, em certos hard cases ${ }^{25}$. E qualquer causa pequena pode tornar-se deontologicamente num caso difícil. Pode haver grandes vitórias de causídicos ou do Ministério Público e outras magistraturas, nos países em que existem, sem perigo, sem dificuldade? Cremos ser difícil. E poderá havê-las com infração de regras deontológicas, com malas artes? Jamais poderá ocorrer.

Evidentemente que essas malas artes podem ser ocultas e de tal forma sinuosas e na sombra que ninguém se dê delas conta, e o(s) jurista(s) em causa (ou sua causa) possa(m) vir até a tornar-se celebradíssimo(s). Não deixa, porém, de ser um caso de consciência complexo o advogado de um inocente, por exemplo, ter de enfrentar o dilema de cometer alguma irregularidade salvando quem deve ser salvo ou não a cometer, condenando-o. Há casos limite em que talvez a honra e a alma do advogado sejam sacrificados para que a Justiça, uma Justiça aparentemente maior, possa triunfar. Mas são daquelas situações que nos deixam incomodados e com vontade de não ser jurista e ter esses problemas, mas por exemplo artista, cujos dilemas especificamente na sua arte (não na dimensão comercial e política da mesma, está claro) ocorrem de forma muito mais plácida. As angústias artísticas soem ser outras. Em luta com o material, com a expressão, com a ideia, com a forma, consigo mesmo...

E contudo, em tempos de subida de autoritarismos e candidatos a totalitarismos, como os nossos, já está claro que a Arte corre riscos. Primeiro de proibição e censura. Depois de sevícias sobre os artistas. E já, certamente, em muitos casos, dessa perversa autocensura daqueles que, para sobreviver ou triunfar, já só produzem o que creem agradar aos vários poderes que decidem, e distribuem os prémios (e as punições, em tempos mais negros). Porém, também é sabido que, como dizia Alain, "pensar é dizer não", e há sempre alguém que o diz, mesmo nos tempos mais tristes. como cantou Manuel Alegre. Ou seja, há sempre quem pense e quem tenha coragem. E isso redime a Arte e a própria natureza ou condição humanas.

24 GOMEZ PEREZ, Rafael - Deontología Juridica, Pamplona, EUNSA, 1982; ARNAUT, António -Iniciação à Advocacia, $8{ }^{\text {a }}$ ed. refundida, Coimbra, Coimbra Editora, 2005.

25 A contrario, v.g., HOVEN, Paul Van Den - Clear Cases: Do they Exist?, in "Revue Internationale de Sémiotique Juridique / International Journal for the Semiotics of Law“, Vol. III, n. ${ }^{\circ}$ 7, 1990, pp. 55-63. 


\section{BIBLIOGRAFIA}

ALVES, João Lopes - Rousseau, Hegel e Marx. Percursos da Razão Política. Lisboa: Livros Horizonte, 1983.

ARNAUT, António -Iniciação à Advocacia, 8. ${ }^{\mathrm{a}}$ ed. refundida, Coimbra, Coimbra Editora, 2005.

BARROS, Gilda Naécia Maciel de - Agraphoi Nomoi. São Paulo: "Notandum", vol. 3, ed. online: http://www. hottopos.com/notand3/agrafoi.htm. Ultimamente consultado em 29 de agosto de 2018.

BECK, Ulrich - Risikogesellschaft, Francoforte-sobre-o-Meno, Suhrkamp,1986.

BONAVIDES, Paulo - Do Estado Liberal ao Estado Social, 7. ${ }^{\mathrm{a}}$ ed., 2. ${ }^{\mathrm{a}}$ tiragem, São Paulo, Malheiros Editores, 2004. BOUTHOUL, Gaston - Les mentalités. Paris: P.U.F., 1952.

ENGELS, Friedrich - A Origem da Família, da Propriedade Privada e do Estado. n/ ed. trad. port. de H. Chaves. Lisboa: Presença, s.d..

ÉSQUILO / SÓFOCLES - Tragiques Grecs. Eschyle / Sophocle. Paris: Gallimard, 1967.

FERREIRA DA CUNHA, Paulo - Para uma Ética Republicana. Lisboa: Coisas de Ler, 2010.

— Le Droit et les Sens. Paris: L'Archer, dif. P.U.F., 2000.

—, O Ponto de Arquimedes. Natureza Humana, Direito Natural, Direitos Humanos, Coimbra, Almedina, 2001.

FINKIELKRAUT, Alain - Un Coeur intelligent. Lectures. Paris: Stock/Flammarion, 2009.

GOMEZ PEREZ, Rafael - Deontología Juridica, Pamplona, EUNSA, 1982.

HAYEK, F. A. - Droit, législation et liberté. I - Règles et ordre, trad. fr.. Paris : PUF, 1973.

HOVEN, Paul Van Den - Clear Cases: Do they Exist?, in "Revue Internationale de Sémiotique Juridique / International Journal for the Semiotics of Law“, Vol. III, n. ${ }^{\circ}$ 7, 1990, pp. 55-63.

KLEIN, Naomi - The Shock Doctrine: The Rise of Disaster Capitalism, 2007. trad. port. de Vania Cury. A Doutrina do Choque: AAscensão do Capitalismo de Desastre. Rio de Janeiro: Nova Fronteira, 2008.

LAFER, Celso - Hannah Arendt. Pensamento, Persuasão e Poder, 2. ${ }^{\text {a }}$ ed., São Paulo, Paz e Terra, 2003.

MALTEZ, José Adelino - Voegelin e a Procura do Direito Natural, Prefácio a A Natureza do Direito e outros textos jurídicos, de Eric Voegelin. Lisboa: Vega, 1998.

MICHELS, Robert - Para uma sociologia dos partidos políticos na democracia moderna: investigação sobre as tendências oligárquicas na vida dos agrupamentos políticos, Lisboa, Antígona, 2000.

MORGAN, Lewis H. - Ancient Society, or researches in the lines of Human Progress from Savagery through Barbarism to Civilization. Londres: Mac Millan, 1877.

PASCAL, Blaise - Pensées, ed. Brunchvicq. Paris: Garnier, 1925, máx. af. 294.

ROUSSEAU, Jean-Jacques - Oeuvres Complètes. Paris: Seuil, 1971, 3 vols.. Contrato Social e o Discurso sobre a origem e os fundamentos da desigualdade entre os homens. trad. port., Porto: Athena, 1964.

TERESA DE ÁVILA, Santa - Moradas do Castelo Interior. trad., introd. e notas de Manuel de Lucena. Lisboa: Assírio \& Alvim, 1988.

TOMÁS DE AQUINO - Summa Theologiae, trad. fr., Somme Théologique. Paris: Cerf, 1984-86, 4 vols..

TZITZIS, Stamatios - Introduction à la philosophie du droit. Paris: Vuibert, 2011.

—, La Formation du droit en Grèce, in Instituições de Direito, org. nossa, vol. I, Coimbra : Almedina, 1998, p. 191 ss...

—, La Philosophie Pénale. Paris: P.U.F., 1996, trad. port., notas e comentários de Mário Ferreira Monte. Filosofia Penal. Porto: Legis, 1999. 